\title{
Destructive effects of prolonged status epilepticus
}

\author{
MELVIN H. EPSTEIN' ${ }^{1}$ AND JOHN S. O'CONNOR
}

\begin{abstract}
From the Division of Neurological Surgery, The Johns Hopkins Hospital, Baltimore, Maryland, U.S.A.
\end{abstract}
\begin{abstract}
Whether permanent cerebral damage occurs during generalized seizure has long been a difficult question to assess. The evaluation of subtle lesions is complicated clinically by the great compensatory powers of the brain and biochemically by the heterogenous composition of nervous tissue. In addition the efficacy of immobilizing the convulsing patient with muscle relaxants such as curare, succinylcholine, or gallamine triethiodide (Thiercelin, 1860) (Bennett, 1940) (Thesleff, 1952), while maintaining normal oxygenation and respiration with intermittent positive pressure, has also been brought into the question.
\end{abstract}

It is the purpose of the present study to evaluate clinically a series of cats which were subjected to prolonged generalized seizure with the 'advantages' of complete muscle relaxation and artificial ventilation. As a measure of the biochemical changes occurring in the neurones of these animals, single Betz cells were isolated at the conclusion of the seizures and their oxygen consumption in glucose medium studied by the Cartesian diver method. It is hoped that the question as to whether 'pure' electrical activity can result in cerebral damage will be more clearly elucidated.

\section{MATERIALS AND METHODS}

THE PRODUCTION OF PROLONGED SEIZURES Convulsions were produced in three groups of cats using penicillin, metrazol, and electroshock so that a broad spectrum of seizure damage could be studied. For the penicillin seizures, the tracheae and femoral veins of two cats were exposed and cannulated under ether anaesthesia. The calvarium was removed and three dural electrodes were placed over each hemisphere for E.E.G. monitoring. At this time the entire scalp and its cutaneous nerves were infiltrated with $1.0 \%$ procaine diluted with $0.9 \%$ normal saline to yield a $0.5 \%$ procaine solution. After all surgical procedures were completed, the administration of ether was suspended and muscular relaxation obtained with $0.1 \mathrm{ml}$. succinylcholine. A respirator was used to maintain normal ventilation while cerebral activity was monitored by the electroencephalogram. This procedure produced serum $\mathrm{CO}_{2}$-combining power values ranging from $17 \cdot 1$ to $24.2 \mathrm{mEq}$./litre as determined at the end of the experimental period.

${ }^{1}$ Henry Strong Denison scholar for 1965-66
After the first 15 minutes of artificial ventilation 6,000 units of crystalline sodium penicillin diluted in $0.1 \mathrm{ml}$. normal saline was injected into the left anterior sigmoid gyrus. The animals convulsed for four hours after which (during an interictal period) both anterior sigmoid gyri were rapidly excised and immersed in liquid propane for cellular analysis. At no time was the interval between excision and freezing greater than six seconds.

Four other cats were prepared the same way except that no craniectomy was performed so that they might be used for clinical follow-up studies after the prolonged seizure. The E.E.G. was monitored through two scalp electrodes placed over each hemisphere and 6,000 units of penicillin was injected through a burr hole into the left anterior sigmoid gyrus. At the end of the four-hour seizure interval $20 \mathrm{mg}$. of diphenylhydantoin (Dilantin) was administered. As soon as the effects of succinylcholine had worn off, the tracheotomy tube was removed and the neck and leg incisions were closed. Blood pressure was monitored using a Statham transducer with a femoral artery catheter and a lead I electrocardiogram was recorded continuously during the experimental period.

Two cats convulsing from metrazol and used for cellular study were operated on in a similar manner as those in the penicillin seizure group. After craniectomy, muscular relaxation with succinylcholine, and normal ventilation were achieved, a total of $2.0 \mathrm{ml}$. of $10 \%$ metrazol in $0.5 \mathrm{ml}$. doses was administered intravenously over a period of 15 minutes to establish status epilepticus. After four hours of seizures, both anterior sigmoid gyri were removed (during an interictal period) and immediately frozen in liquid propane for cellular study.

In addition, four animals convulsing from metrazol were prepared so that they might be studied without a craniectomy. The blood pressure and E.C.G. were recorded and $20 \mathrm{mg}$. of diphenylhydantoin (Dilantin) was administered followed by removal of the tracheotomy tube.

Seizures were produced by subjecting two cats to a series of transfrontal electric shocks at 80 volts for a duration of 0.5 seconds after having been prepared similarly to the penicillin focus cat used for cellular study. The number of shocks required to put the cats into status epilepticus varied from four to 20 . However, in each case the seizures continued for four hours before the anterior sigmoid gyri were excised and frozen for analysis. Normal ventilation was achieved as before with succinylcholine and a respirator.

Four other cats were also allowed to convulse for four hours being stimulated by electroshock. They were studied clinically after the seizures. Once again the blood pressure, E.E.G., and E.C.G. were recorded. 
Craniectomy was not performed on these animals and the tracheotomy and femoral incisions were closed following the procedure.

Four control cats were prepared similarly to the animals used for the cellular study in the penicillin preparation except that no seizures were produced. Following craniectomy, muscular relaxation with succinylcholine, and a four-hour interval of normal ventilation, both anterior sigmoid gyri were excised and frozen in liquid propane. An additional series of four control animals was studied clinically following tracheotomy, femoral vein catheterization, and normal ventilation on a respirator for a period of four hours. The blood pressure, E.C.G. and E.E.G. were monitored during the experimental period.

DISSECTION TECHNIQUE The technique for removing single cortical neurones has been described in detail in a previous publication (Epstein and O'Connor, 1965) and will only be briefly outlined below. The frozen gyrus was mounted in a cryostat and a section 50-60 $\mu$ was cut. The section was allowed to thaw on a warm glass slide and after an interval of 60 seconds, $0.01 \%$ methylene blue in $0.9 \%$ saline was applied to the tissue for cell visualization and allowed to remain for 30 seconds. The slide was then washed with a few drops of substrate buffer and a second application was allowed to remain oi the tissue throughout the dissection. Using a Caillouf micromanipulator, the Betz cells were teased out under the $\times 200$ magnification system of the Zeiss invertef microscope. The neurones were then washed by being transferred in a siliconed micro-pipette to a depression slide filled with a few drops of substrate buffer. The were then photographed to make possible planimetrie area determinations, and their thickness was measured by using the vernier dial of the vertical control of the microscope stage. With $A$ and $C$ representing the area an thickness respectively, the formula $\mathrm{V}=2 / 3 \mathrm{AC}$ (Mickle: wright, Kurnick, and Hodes, 1953) was then used to approximate the volume. The method has a mean errof of $30 \%$ and the volumes determined therefore have onf relative significance.

SUBSTRATE BUFFER The sterile substrate buffer consisted of $3.5 \mathrm{ml}$. of $0.2 \mathrm{M} \mathrm{Na}_{2} \mathrm{HPO}_{4}, 9.0 \mathrm{ml}$. of $0.2 \mathrm{M}$ $\mathrm{NaH}_{2} \mathrm{PO}_{4}, 0.203 \mathrm{~g}$. NaCl , and $10 \mathrm{ml} .5 \%$ glucose diluted in $77.5 \mathrm{ml} . \mathrm{H}_{2} \mathrm{O}$. The final solution had a $p \mathrm{H}$ of $7 \cdot 3$, afp effective milliosmolality of 285 , and a glucose con centration of $500 \mathrm{mg} . \%$.

TABLE I

CLINICAL PARAMETERS OF 26 ANIMALS BEFORE AND AFTER PROLONGED SEIZURES PRODUCED BY THREE DIFFERENT METHADS

Before Seizure

\begin{tabular}{|c|c|c|}
\hline $\begin{array}{l}\text { Cat } \\
\text { No. }\end{array}$ & $\begin{array}{l}\text { Blood } \\
\text { Pressure } \\
\text { (mm, Hg) }\end{array}$ & E.C.G. \\
\hline
\end{tabular}

After Seizure

\begin{tabular}{llll}
\hline Blood & E.C.G. & Pulse & Time of \\
Pressure & & Beats & Death \\
$(\mathrm{mm} . \mathrm{Hg})$ & & $(/ \mathrm{min})$. & (hours ofeñ
\end{tabular}

operation) $\rightarrow$

\begin{tabular}{|c|c|c|c|c|c|c|c|c|}
\hline $\begin{array}{l}\text { Metrazol } \\
\text { Clinical }\end{array}$ & $\begin{array}{l}\mathbf{A} \\
\mathbf{B} \\
\mathbf{C} \\
\mathbf{D}\end{array}$ & $\begin{array}{l}120 / 75 \\
125 / 70 \\
125 / 75 \\
120 / 75\end{array}$ & $\begin{array}{l}\text { Normal sinus rhythm } \\
\text { Normal sinus rhythm } \\
\text { Normal sinus rhythm } \\
\text { Normal sinus rhythm }\end{array}$ & $\begin{array}{l}240 \\
230 \\
250 \\
245\end{array}$ & $\begin{array}{l}150 / 90 \\
145 / 85 \\
155 / 90 \\
150 / 95\end{array}$ & $\begin{array}{l}\text { Normal sinus rhythm } \\
\text { Occasional ventricular } \\
\text { ectopic focus } \\
\text { Occasional widening of } \\
\text { QT interval } \\
\text { Normal sinus rhythm }\end{array}$ & $\begin{array}{r}110 \\
90 \\
100 \\
110\end{array}$ & 27 \\
\hline Cellular & $\begin{array}{l}\mathbf{E} \\
\mathbf{F}\end{array}$ & $\begin{array}{l}130 / 75 \\
125 / 70\end{array}$ & $\begin{array}{l}\text { Normal sinus rhythm } \\
\text { Normal sinus rhythm }\end{array}$ & $\begin{array}{l}245 \\
240\end{array}$ & $\begin{array}{l}150 / 90 \\
150 / 85\end{array}$ & $\begin{array}{l}\text { Normal sinus rhythm } \\
\text { Normal sinus rhythm }\end{array}$ & $\begin{array}{r}100 \\
95\end{array}$ & - \\
\hline $\begin{array}{l}\text { Penicillin } \\
\text { Clinical }\end{array}$ & $\begin{array}{l}\mathbf{G} \\
\mathbf{H} \\
\mathbf{I} \\
\mathbf{J}\end{array}$ & $\begin{array}{l}130 / 75 \\
125 / 75 \\
120 / 70 \\
120 / 70\end{array}$ & $\begin{array}{l}\text { Normal sinus rhythm } \\
\text { Normal sinus rhythm } \\
\text { Normal sinus rhythm } \\
\text { Normal sinus rhythm }\end{array}$ & $\begin{array}{l}235 \\
245 \\
240 \\
240\end{array}$ & $\begin{array}{l}155 / 85 \\
150 / 90 \\
150 / 95 \\
155 / 90\end{array}$ & $\begin{array}{l}\text { Normal sinus rhythm } \\
\text { Normal sinus rhythm } \\
\text { Normal sinus rhythm } \\
\text { Normal sinus rhythm }\end{array}$ & $\begin{array}{l}100 \\
100 \\
105 \\
115\end{array}$ & $\begin{array}{l}24 \\
20 \\
28 \\
15\end{array}$ \\
\hline Cellular & $\begin{array}{l}\mathbf{K} \\
\mathbf{L}\end{array}$ & $115 / 70$ & $\begin{array}{l}\text { Normal sinus rhythm } \\
\text { Normal sinus rhythm }\end{array}$ & $\begin{array}{l}250 \\
240\end{array}$ & $145 / 90$ & $\begin{array}{l}\text { Normal sinus rhythm } \\
\text { Normal sinus rhythm }\end{array}$ & $\begin{array}{l}95 \\
90\end{array}$ & $\overline{-}$ \\
\hline $\begin{array}{l}\text { Electro- } \\
\text { shock } \\
\quad \text { Clinical }\end{array}$ & $\begin{array}{l}\mathbf{M} \\
\mathbf{N} \\
\mathbf{O} \\
\mathbf{P}\end{array}$ & $\begin{array}{l}125 / 75 \\
120 / 70 \\
- \\
120 / 75\end{array}$ & $\begin{array}{l}\text { Normal sinus rhythm } \\
\text { Normal sinus rhythm } \\
\text { Normal sinus rhythm } \\
\text { Normal sinus rhythm }\end{array}$ & $\begin{array}{l}240 \\
255 \\
220 \\
210\end{array}$ & $\begin{array}{l}150 / 95 \\
155 / 90 \\
- \\
160 / 95\end{array}$ & $\begin{array}{l}\text { Normal sinus rhythm } \\
\text { Normal sinus rhythm } \\
\text { Normal sinus rhythm } \\
\text { Normal sinus rhythm }\end{array}$ & $\begin{array}{r}95 \\
100 \\
105 \\
100\end{array}$ & $\begin{array}{l}37 \\
28 \\
32 \\
19\end{array}$ \\
\hline Cellular & $\mathbf{Q}$ & $\begin{array}{l}135 / 75 \\
120 / 70\end{array}$ & $\begin{array}{l}\text { Normal sinus rhythm } \\
\text { Normal sinus rhythm }\end{array}$ & $\begin{array}{l}240 \\
235\end{array}$ & $\begin{array}{l}150 / 95 \\
145 / 90\end{array}$ & $\begin{array}{l}\text { Normal sinus rhythm } \\
\text { Normal sinus rhythm }\end{array}$ & $\begin{array}{r}100 \\
95\end{array}$ & - \\
\hline $\begin{array}{l}\text { Control } \\
\text { Clinical }\end{array}$ & $\begin{array}{l}\mathbf{S} \\
\mathbf{T} \\
\mathbf{U} \\
\mathbf{V}\end{array}$ & $\begin{array}{l}120 / 70 \\
115 / 75 \\
125 / 75 \\
120 / 75\end{array}$ & $\begin{array}{l}\text { Normal sinus rhythm } \\
\text { Normal sinus rhythm } \\
\text { Normal sinus rhythm } \\
\text { Normal sinus rhythm }\end{array}$ & $\begin{array}{l}230 \\
230 \\
225 \\
240\end{array}$ & $\begin{array}{l}120 / 75 \\
120 / 75 \\
125 / 75 \\
125 / 75\end{array}$ & $\begin{array}{l}\text { Normal sinus rhythm } \\
\text { Normal sinus rhythm } \\
\text { Normal sinus rhythm } \\
\text { Normal sinus rhythm }\end{array}$ & $\begin{array}{l}235 \\
230 \\
225 \\
235\end{array}$ & $\frac{-}{-}$ \\
\hline Cellular & $\begin{array}{l}\mathbf{W} \\
\mathbf{X} \\
\mathbf{Y} \\
\mathbf{Z}\end{array}$ & $\begin{array}{l}125 / 70 \\
120 / 65 \\
\frac{120 / 75}{}\end{array}$ & $\begin{array}{l}\text { Normal sinus rhythm } \\
\text { Normal sinus rhythm } \\
\text { Normal sinus rhythm } \\
\text { Normal sinus rhythm }\end{array}$ & $\begin{array}{l}245 \\
240 \\
235 \\
220\end{array}$ & $\begin{array}{l}125 / 70 \\
120 / 70 \\
\overline{120 / 75}\end{array}$ & $\begin{array}{l}\text { Normal sinus rhythm } \\
\text { Normal sinus rhythm } \\
\text { Normal sinus rhythm } \\
\text { Normal sinus rhythm }\end{array}$ & $\begin{array}{l}250 \\
245 \\
235 \\
220\end{array}$ & $\begin{array}{l}- \\
-\end{array}$ \\
\hline
\end{tabular}


THE CARTESIAN DIVER TECHNIQUE The modified ampulla diver technique was used to determine the oxygen consumption of cells incubated in glucose (LinderstrømLang, 1937; Zeuthen, 1953; Zajicek and Zeuthen, 1956). Individual Betz cells were introduced into the tip of a capillary diver together with approximately 0.5 to $1.0 \mu \mathrm{l}$. of buffer medium. The ampulla was charged with air while the tail and flotation chamber were filled with $0.1 \mathrm{~N}$ $\mathrm{NaOH}$. The diver was introduced into the flotation chamber whose temperature was maintained at $37.0^{\circ} \mathrm{C}$. $\pm 0.001^{\circ} \mathrm{C}$., and was allowed to equilibrate for two hours. Subsequently, measurements were taken every half hour for at least three hours longer. The sensitivity of the method is in the order of magnitude of $10^{-4} \mu 1.0_{2}$ /hour with an accuracy of 5 to $10 \%$. The gas exchange per unit time was calculated from the formula previously presented by Zeuthen (1953).

\section{RESULTS}

Table I shows the operative and post-operative history of each animal used in this series of experi-

\section{TABLE II}

OXYGEN UPTAKE OF 34 BETZ CELLS REMOVED FROM EITHER THE RIGHT OR LEFT HEMISPHERE

$$
\text { Cat Cell Volume }\left(\mu^{3}\right) \quad 10^{-4} \mu 1 \cdot 0_{\mathrm{a}} / \text { hour }
$$

\begin{tabular}{|c|c|c|c|c|}
\hline & Cat & Cell & Volume $\left(\mu^{3}\right)$ & $10^{-4}$ \\
\hline Metrazol & $\begin{array}{l}\mathbf{E} \\
\mathbf{E} \\
\mathbf{E} \\
\mathbf{F} \\
\mathbf{F} \\
\mathbf{F}\end{array}$ & $\begin{array}{ll}1 & R \\
2 & L \\
3 & R \\
4 & L \\
5 & R \\
6 & L\end{array}$ & $\begin{array}{l}52,700 \\
49,300 \\
46,200 \\
51,700 \\
\overline{47,300}\end{array}$ & 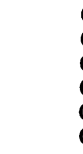 \\
\hline $\begin{array}{l}\text { Penicillin } \\
\text { focus }\end{array}$ & $\begin{array}{l}\mathbf{K} \\
\mathbf{K} \\
\mathbf{K} \\
\mathbf{L} \\
\mathbf{L} \\
\mathbf{L}\end{array}$ & $\begin{array}{r}7 \mathrm{R} \\
8 \mathrm{~L} \\
9 \mathrm{R} \\
10 \mathrm{~L} \\
11 \mathrm{R} \\
12 \mathrm{~L}\end{array}$ & $\begin{array}{l}15,700 \\
28,000 \\
36,100 \\
\overline{88,400} \\
50,200\end{array}$ & c \\
\hline $\begin{array}{l}\text { Electro- } \\
\text { shock }\end{array}$ & $\begin{array}{l}\mathbf{Q} \\
\mathbf{Q} \\
\mathbf{Q} \\
\mathbf{R} \\
\mathbf{R} \\
\mathbf{R}\end{array}$ & $\begin{array}{l}13 \mathrm{R} \\
14 \mathrm{~L} \\
15 \mathrm{R} \\
16 \mathrm{~L} \\
17 \mathrm{R} \\
18 \mathrm{~L}\end{array}$ & $\begin{array}{l}45,400 \\
41,400 \\
61,200 \\
61,200 \\
41,400 \\
45,400\end{array}$ & 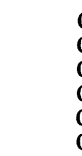 \\
\hline Control & $\begin{array}{l}\mathbf{W} \\
\mathbf{W} \\
\mathbf{W} \\
\mathbf{W} \\
\mathbf{X} \\
\mathbf{X} \\
\mathbf{X} \\
\mathbf{X} \\
\mathbf{Y} \\
\mathbf{Y} \\
\mathbf{Y} \\
\mathbf{Y} \\
\mathbf{Z} \\
\mathbf{Z} \\
\mathbf{Z} \\
\mathbf{Z}\end{array}$ & $\begin{array}{l}19 \mathrm{R} \\
20 \mathrm{~L} \\
21 \mathrm{R} \\
22 \mathrm{~L} \\
23 \mathrm{R} \\
24 \mathrm{~L} \\
25 \mathrm{R} \\
26 \mathrm{~L} \\
27 \mathrm{R} \\
28 \mathrm{~L} \\
29 \mathrm{R} \\
30 \mathrm{~L} \\
31 \mathrm{R} \\
32 \mathrm{~L} \\
33 \mathrm{R} \\
34 \mathrm{~L}\end{array}$ & $\begin{array}{l}11,300 \\
47,500 \\
93,900 \\
42,600 \\
38,100 \\
46,300 \\
12,000 \\
62,200 \\
55,700 \\
35,800 \\
36,800 \\
56,100 \\
42,000 \\
41,000 \\
44,300 \\
38,000\end{array}$ & $\begin{array}{r}19 \\
11 \\
12 \\
15 \\
12 \\
17 \\
9 \\
9 \\
10 \\
11 \\
11 \\
10 \\
13\end{array}$ \\
\hline
\end{tabular}

ments. It can be seen that all cats subjected to prolonged metrazol, penicillin, and electroshock seizures died within eight to 48 hours post-operatively. At the conclusion of the seizures, the pulse rate was found to be lower and the blood pressure higher in all cases. The E.C.G. was normal throughout the experimental series, except in those animals convulsing with metrazol who occasionally would exhibit a ventricular ectopic focus or a transient widening of the QT interval. All animals were comatose post-operatively until the time of death. All had moderately dilated fixed pupils except cat $\mathbf{G}$ whose pupils reacted normally to light until the 17th hour post-operatively. At that time both pupils were found to be fixed and dilated. Cats $\mathrm{G}$ and $\mathrm{N}$ exhibited primitive walking movements and all animals were relatively flaccid and hypotonic in the agonal period. The E.E.G. appeared normal on all the pre-seizure tracings; however, at the termination of the experiment there was virtually no evidence of electrical activity.

On the clinically studied control animals, the E.E.G., E.C.G., blood pressure, and pulse rate remained approximately normal throughout the experimental period. All animals were awake and ambulant within 24 hours post-operatively.

In all, 34 cells were studied from both convulsing and control animals. No detectable oxygen uptake was obtained from any of the convulsing animals; however, the control group demonstrated an average uptake of $10 \cdot 7 \times 10^{-4} \mu 1 \cdot 0_{2} /$ hour (Table II).

\section{DISCUSSION}

In this study seizures were initiated by three methods so that the clinical response of the animals could be studied and the side effects of the convulsive agents compared. All animals were tracheotomized and maintained on supportive respiration to ensure adequate pulmonary ventilation throughout the seizures. It is therefore of interest that despite muscular relaxation and adequate oxygenation the animals still suffered irreversible damage which ultimately led to their demise. One explanation could be that prolonged seizure eventually leads to cerebral oedema which in turn is exacerbated by the resulting venous stasis. This is supported by the data in this paper which show that at the termination of the experiment the blood pressure was significantly higher and the pulse rate significantly lower than at the beginning of the experiment. In fact the necropsied brains in the present study did reveal a moderate degree of swelling but no other visible lesions. Hendley, Spudis, and De La Torre (1965) and McQueen and Jeanes (1962) have demonstrated an increase in intracranial pressure associated with both 
electroshock and spontaneous seizures in paralysed animals. The exact mechanism of these changes is still not clear.

Another possibility is that during convulsions a relative anoxia exists which continues during prolonged seizure resulting in temporary or even permanent damage to cerebral tissue. It has long been known that stimulation of brain slices increases their uptake of oxygen (McIlwain, 1953). Also Davies and Rémond (1947) have demonstrated that there is an increase in oxygen consumption during metrazol seizure which exceeds the increased rate of delivery resulting from augmented blood flow. In addition one must consider the work of Gurdjian, Webster, and Stone (1947) and Jasper and Erickson (1941) who demonstrated that hypoxia will spontaneously stop metrazol seizures. In the present study we may well be interfering with a normal cerebral protective mechanism by maintaining adequate ventilation throughout the convulsion.

It is interesting to note that in no instance did the isolated Betz cells from convulsing animals demonstrate measurable oxygen uptake. Because of the method used in preparation of these neurones the lack of oxygen uptake does not necessarily indicate the death of these cells but does strongly point to the possibility that some biochemical factor has been depleted during the seizures. Whether this derangement is secondary to the loss of an enzyme cofactor, to cellular leakage of potassium, or to alterations resulting from increased concentrations of metabolic by-products is difficult to determine at this time. It is certain, however, that there are considerable changes in the neurones following prolonged seizures despite the presence of adequate ventilation.

It is well known that although some epileptics suffer from numerous attacks with no obvious damage to behaviour patterns or mental capacity, other cases are marked by advancing deterioration. Penfield and Jasper (1954) describe advancing cerebral atrophy with enlargement of the ventricles and intergyral spaces confirmed by pneumography in epileptic patients not suffering from known degenerative diseases. He further states that seizures which are not generalized are less apt to result in permanent damage. The more severe and longer the duration of attacks the greater the danger of permanent cerebral injury.

To extend the present study from the laboratory to the human patient is a problem because of the difficulties in controlling the pathological lesions producing seizure and the magnitude and time interval of the fit. In this investigation we have produced convulsions of great intensity and of measured duration. Although we cannot at this time elucidate the precise means by which cerebral damage comes about, the results suggest that the electrical activit产 in severe seizures is itself capable of causing certaik irreversible changes despite adequate ventilation.

\section{SUMMARY}

A series of cats were immobilized with succinyl choline, tracheotomized, and maintained on a respi ․․․ rator while prolonged seizures were conducted witli metrazol, penicillin, or electroshock. One group of animals had individual Betz cells removed and waş studied in the Cartesian diver for oxygen uptake ${ }_{0}^{+}$ The remaining animals were allowed to recoves from the muscle relaxant and studied clinically.

Despite adequate ventilation all animals in the seizure group studied clinically expired within $48^{\circ}$ hours following termination of the convulsions. Alf cells studied from the seizure animals showed $\vec{b}$ serious alteration in their metabolic potential.

The authors wish to thank Professor A. Earl Walker for his helpful advice during the course of this work, and Miss Diana Miller for her skilful assistance. The presenf study was supported by grants from the National Instiє€ tutes of Health and the American Cancer Society.

\section{REFERENCES}

Bennett, A. E. (1940). Preventing traumatic complications in conerlsive shock therapy by curare. J. Amer. med. Ass., 114, 322-324.C

Davies, P. W., and Rémond, A. (1947). Oxygen consumption of ghe cerebral cortex of the cat during metrazol convulsions. $\mathrm{E}$ sid Publ. Ass. nerv. ment. Dis., 26, 205-217.

Epstein, M. H., and O'Connor, J. S. (1965). Respiration of sisise cortical neurons and of surrounding neuropile. J. Neurochest. 12, 389-395.

Gurdjian, E. S., Webster, J. E., and Stone, W. E. (1947). CerebraD metabolism in metrazol convulsions in the dog. Res. Publo Ass. nerv. ment. Dis., 26, 184-204.

Hendley, C. D., Spudis, E. V., and De La Torre, E. (1965). Intrā̄ cranial pressure during electroshock convulsions in the dog Neurology (Minneap.), 15, 351-360.

Jasper, H., and Erickson, T. C. (1941). Cerebral blood flow and pH in excessive cortical discharge induced by metrazol and electrical stimulation. J. Neurophysiol., 4, 333-347.

Linderstrøm-Lang, K. (1937). Principle of the Cartesian diver appliedB to gasometric technique. Nature (Lond.), 140, 108.

McIlwain, H. (1953). Substances which support respiration and metabolic response to electrical impulses in human cerebraP. tissues. J. Neurol. Neurosurg. Psychiat., 16, 257-266.

McQueen, D. J., and Jeanes, L. D. (1962). Influence of hypothermia on intracranial hypertension. J. Neurosurg., 19, 277-288.

Micklewright, H. L., Kurnick, N. B., and Hodes, R. (1953). The determination of cell volume. Exp. Cell Res., 4, 151-158.

Penfield, W., and Jasper, H. (1954). Epilepsy and the Functionat. Anatomy of the Human Brain, p. 274. Little, Brown, and Co.? Boston.

Thesleff, S. (1952). Succinylcholine iodide-studies on its pharmo cological properties and clinical use. Acta physiol. scand., 27은 suppl. 99.

Thiercelin, L. (1860). Note sur l'emploi du curare dans le traitement les néuroses convulsives et en particulier dans celui d'épilepsie으. C. R. Acad. Sci. (Paris), 51, 716-719.

Zajicek, J., and Zeuthen, E. (1956). Quantitative determination of cholinesterase activity in individual cells Exp. Cell Res.; 11, 568-579.

Zeuthen, E. (1953). Growth as related to the cell cycle in single-celf cultures of tetrahymena piriformis. J. Embryol. exp. Morph. $\omega$ 1, 239-249. 